UMBARTA

Indonesian Journal of Anthropology

Volume 5 (2) Desember 2020 || eISSN 2528-1569 | pISSN 2528-2115 || http://jurnal.unpad.ac.id/umbara

DOI : $10.24198 /$ umbara.v5i2.25504

\title{
Mendobrak Dominasi Sejarah: Upaya Laboratorium Banten Girang (LBG) dalam Mengenalkan Kembali Sejarah Pra-Islam dan Tinggalannya di Banten
}

\author{
Nilam Gita Perdana \\ Departemen Antropologi Budaya, Fakultas Ilmu Budaya, Universitas Gadjah Mada \\ nilamgitap96@gmail.com
}

\begin{abstract}
Banten has experienced long chronological history that shaped its society's culture today. This study discusses activities by a community named "Laboratorium Banten Girang" (known as LBG) in Serang, Banten. The community aims at introducing a non-dominant history in Banten, and at the same time promote it as cultural heritage into the public space. In this study, the history of Banten presented in two sections; dominant and non-dominant history. Data in this study were collected through observation and in-depth interviews to members of the LBG, and residents living in the historical site of Banten. Results of this study suggests that LBG brings discourse outside the official or authorized discourse of the dominant history and try to introduce the other side of the story of Banten history; dating back to pre-Islamic history and its heritage. In their activities, the LBG do not aim to repair or to beautify the existing heritage and history, but they reintroduce it through various activities instead. Their effort receive diverse responses from society both rejection and acceptance. Meanwhile, the discourse carried by LBG indirectly serves as a non-physical revitalization project on cultural heritage and an effort to realize the ideas of the advancement of Banten's culture.
\end{abstract}

Keywords: community, cultural heritage, dominant history, non-dominant history, discourse

\begin{abstract}
Abstrak
Banten telah mengalami kronologi sejarah panjang yang membentuk kebudayaan masyarakat hingga hari ini. Penelitian ini membahas sebuah komunitas bernama "Laboratorium Banten Girang" (LBG) yang berupaya memperkenalkan sejarah tidak dominan di Banten dan menjadikannya sebagai warisan budaya di ruang publik. Komunitas ini merintis misinya di Kota Serang, Banten. Pada penelitian ini, berbagai peristiwa yang melingkupi sejarah Banten dibahas dalam dua bagian cerita sejarah, yaitu sejarah dominan dan tidak dominan. Data dalam studi ini diperoleh melalui metode observasi dan wawancara mendalam. Hasil penelitian ini menunjukkan bahwa komunitas LBG membawa diskursus di luar diskursus resmi tentang sejarah Banten dan berusaha memperkenalkan sisi lain dari sejarah Banten, yaitu dimulai dari sejarah pra-Islam beserta tinggalannya. Mereka tidak berusaha memperbaiki atau mempercantik
\end{abstract}


warisan budaya yang telah ada, tetapi mengenalkan kembali sejarah itu melalui berbagai kegiatan. Kegiatan yang dilakukan LBG menuai respon beragam dari masyarakat. Sementara itu, diskursus yang diusung oleh komunitas LBG secara tidak langsung juga merupakan proyek revitalisasi non-fisik pada warisan budaya dan upaya mewujudkan cita-cita pemajuan kebudayaan Banten.

Kata kunci: komunitas, warisan budaya, sejarah dominan, sejarah tidak dominan, diskursus

\section{Pendahuluan}

Kronologi peristiwa masa lampau yang dikenal dengan 'sejarah' terus direproduksi oleh mereka yang berkepentingan melestarikan dan menurunkan cerita tersebut pada generasi selanjutnya. Hal ini dilakukan melalui berbagai metode, baik oral (lisan), catatan tertulis, maupun dalam berbagai bentuk dokumentasi lainnya. Bagi sebagian besar orang, sejarah dianggap sebagai refleksi untuk menjalankan kehidupan di hari ini atau yang akan datang. Di dalam perkembangannya, cerita sejarah kerap mengalami pembiasan, sehingga kerap menimbulkan keraguan di masyarakat mengenai kebenarannya. Pembiasan ini terjadi karena adanya penambahan atau pengurangan, bahkan pembelokan jalan cerita yang dipengaruhi berbagai faktor. Kelley (1998) menjelaskan bahwa:

\section{"A history of "history" itself can be written with reference to all of these variables, including the psychology, social status, political standpoint, and cultural environment of particular historians; but it can also be written in the phenomenological terms of the historical genre itself and the surviving values which have become part of the basic vocabulary and mentality of historians."}

Di antara ragam peristiwa sejarah di Nusantara, salah satu kronologi yang tidak dapat dilewati adalah sejarah keberadaan Banten. Ketiban inten, bantahan, sesajen, adalah sebagian dari berbagai penafsiran asal usul nama "Banten" yang berkembang di masyarakat. Oleh bangsa lain, Banten juga disebut Bantam
(Bahasa Belanda) dan Shu-t'a dalam perjalanan Cheng Ho yang berarti Sunda. Munculnya berbagai versi nama ini mencerminkan realitas sosial yang pernah, sedang, atau bahkan yang mungkin akan dihadapi oleh Banten nantinya. Nama Banten diduga muncul pertama kali dalam laporan perjalanan Tome Pires tahun 1513 sebagai salah satu bandar Kerajaan Sunda yang cukup ramai (Ayatrohaedi, 1995). Sementara itu, penafsiran lain menyebut bahwa nama Banten" sebagai kata lain dari "sesaji” dinilai lebih tepat karena menunjukkan awal perkembangan kebudayaan di Banten dengan ditemukannya piranti pemujaan di berbagai wilayah.

Tihami (2018) menyebut Banten sebagai "komunitas kultural" yang kebudayaannya dapat diamati melalui unsur-unsur kebudayaan, terutama pada dimensi fisik dan kelakuan (perbuatan) dengan melihat sisi-sisi tradisi dan sisa-sisa peninggalan fisik di Banten yang dapat diinterprestasikan secara simbolik. Di samping itu, kondisi alam Banten yang beragam di setiap wilayahnya ikut mempengaruhi kehidupan sosio-kultural masyarakat. Jalur perairan Banten secara historis membentuk masyarakatnya menjadi multi etnis, multi bahasa, multi agama, serta budaya. Hal ini karena berbaurnya masyarakat Banten dengan etnis dan bangsa lain yang datang berlayar ke wilayah itu. Banten pun tumbuh menjadi wilayah yang terbuka dan berkehidupan harmonis.

Kedatangan bangsa lain di Banten diduga telah terjadi sejak abad pertama Masehi dengan diberlakukanya jalur pelayaran internasional yang menjadikan Banten sebagai tempat tujuan pelayaran, terutama bidang perniagaan. Catatan per-

\footnotetext{
1 Bagi umat Hindu Bali, Banten (sesajen) adalah simbol yang digunakan dalam upacara yang merupakan implementasi dari konsep Tri Hita Karana yang dijadikan pijakan ajaran agar manusia mengupayakan hubungan harmonis dengan Tuhan, dengan sesama manusia, dan dengan alam lingkungannya (Wiana, 2007; Hariana, 2017).
} 
jalanan Tome Pires menyebutkan bahwa Banten merupakan salah satu Bandar Kerajaan Sunda yang melakukan perniagaan dengan kepulauan Maladiva dan Sumatera dengan memperdagangkan beras, berbagai jenis makanan, dan lada (Cortesão, 1994). Maka tidak heran apabila Banten banyak menjalin hubungan dengan "dunia luar", baik dalam urusan perniagaan maupun keagamaan, terutama dengan India dan Cina.

Pada "Naskah Kerajaan-kerajaan di Bumi Nusantara" yang terbit pada 1599 Saka/1677 Masehi, disebutkan bahwa wilayah Jawa Barat sebelah Barat yang merujuk pada Banten telah diduduki oleh beberapa kerajaan sejak awal abad pertama. Raja-raja yang berhasil berkuasa sebagian besar merupakan keturunan Bharata (India) yang kemudian bersama dengan pasukannya memperistri pribumi dan menetap di bumi Nusantara. Masyarakat di kerajaan itu diduga ikut menganut agama pemimpin mereka yang bercorak Hindu-Budha. Hal ini didukung dengan ditemukannya berbagai artefak di tempat yang diduga menjadi wilayah kekuasaan kerajaan tersebut. Salah satu kerajaan yang pernah berkuasa di Ujung Barat Jawa Barat ini adalah Salakanagara. Menurut penyelidikan Anwas Adiwilaga (dalam Halwany dan Chudari, 1993), Salakanagara merupakan kerajaan tertua di Jawa Barat yang didirikan di Pulau Panaitan pada tahun 130 dan merupakan cikal bakal kerajaan Tarumanegara.

Peninggalan yang diduga berasal dari masa pra-Islam di Banten yang ditemukan para ahli, sedikit mencerahkan data bahwa telah ada peradaban dengan kebudayaan yang mengacu pada kehidupan berkepercayaan yang diturunkan oleh leluhur, animisme, dinamisme, hingga Hindu-Budha. Artinya, Banten bukanlah wilayah yang baru memulai 'kehidupan' sejarahnya ketika terjadi dan setelah masa pengislaman. Oleh karena itu, sebagian orang menggagas perlunya mengangkat kembali sejarah pra-Islam di Banten yang masih terbatas sumber data dan peninggalannya. Sejarah pra-Islam yang dianggap "gelap" oleh Guillot, et al. (1997) ini diharapkan dapat digali atau direkonstruksi sebagai tambahan pengetahuan mengenai perkembangan kebudayaan di Banten dan mengisi sela waktu dalam kronologi sejarah Banten pra-Islam yang dianggap hilang.

Warisan budaya masih belum dapat dipisahkan dari persoalan sejarah dominan yang melatarbelakanginya. Hal ini termasuk dalam hal upaya revitalisasi budaya yang sebagian besar lebih fokus pada objek massal dan dominan. Fenomena ini mendorong beberapa pihak untuk bersepakat membangkitkan kembali pengetahuan mengenai kebudayaan Banten secara holistik. Hal ini dimaksudkan untuk melepas selimut stigma yang mengarah pada vonis agama atas keberatannya terhadap kebudayaan masa lampau (pra-Islam) yang dapat menggeser pemaknaan warisan budaya tidak dominan. Upaya mewacanakan kembali sejarah pra-Islam ini dilakukan sebagai gerakan "peka terhadap kebudayaan" yang salah satunya disuarakan oleh komunitas Laboratorium Banten Girang (LBG) di Kota Serang, Banten.

\section{Kajian Pustaka}

Cerita sejarah beserta bangunan yang masih kokoh berdiri sebagai artefak masa lalu adalah bukti atas peristiwa yang pernah terjadi di suatu wilayah. Berbagai produk budaya pun dirangkai untuk menyambung benang merah atas suatu peristiwa tersebut. Di satu sisi, masih banyak produk budaya yang diabaikan keberadaannya sebagai warisan budaya, baik warisan benda maupun tak benda.

Cukup banyak kajian yang membahas tentang warisan budaya baik di tingkat lokal maupun internasional. Di antaranya terfokus pada proses rekonstruksi, pelestarian, ataupun revitalisasi secara fisik terhadap warisan budaya tersebut. Sebagian besar kajian itu berasal dari disiplin ilmu yang akrab dengan warisan budaya, yaitu arkeologi dan sebagian lagi dari sejarah. Sejak 1970-an para antropolog pun telah banyak yang semakin tertarik pada ranah sejarah (Kuper dalam Byrne, 2008).

Di dalam beberapa kasus, pemberdayaan komunitas sekitar situs oleh pihak-pihak yang berkepentingan menjadi daya tarik banyak 
peneliti dalam konteks kajian yang bersinggungan dengan heritage ini. Pemberdayaan masyarakat pada hakikatnya adalah bentuk perubahan yang prosesnya tidak akan berjalan tanpa adanya perubahan budaya yang dilakukan oleh masyarakat (Gasani, 2019). Selain itu, kajian tentang pemberdayaan masyarakat sekitar situs juga terjadi karena adanya tekanan pada warisan budaya tersebut berupa ancaman perusakan atau semacamnya.

Komunitas Laboratorium Banten Girang (LBG) dalam penelitian ini adalah sebuah komunitas yang bersifat luas. Anggota komunitas ini sebagian besar adalah pendatang, bukan berasal dari lokasi keberadaan heritage, yang berusaha menggunakan heritage sebagai ruang publik. Prabowo dan Ma'ruf (2016) menyebut bahwa suatu komunitas dapat memanfaatkan situs sebagai ruang publik, tetapi tidak secara spesifik untuk mengenalkan kembali seni dan budaya untuk dipublikasikan.

Pembahasan mengenai heritage tidak hanya berbicara tentang kebendaannya saja, melainkan dapat melalui cerita sejarahnya yang tidak banyak dikenal oleh masyarakat pada hari ini. Seringkali penolakan masyarakat pada suatu cerita sejarah terjadi karena dianggap tidak sesuai dengan kepercayaan dominan yang ada. Marbun (2016) menjelaskan bahwa komunitas yang berusaha mendorong masyarakat lokal, ironisnya seringkali justru ditimpa isu mempertahankan kepercayaan di luar apa yang dipercayai oleh penduduk lokal. Sentimen inilah yang kemudian menjadi dasar munculnya gagasan untuk mewacanakan hal baru dalam upaya memaknai warisan budaya, sekaligus memanfaatkan peninggalan sejarah tersebut sebagai ruang publik untuk pengedukasian sejarah tidak dominan.

\section{Heritage}

'Heritage' dalam bahasa Indonesia berarti warisan, pusaka, atau peninggalan. Di dalam kamus Oxford, heritage didefinisikan sebagai 'property that is or may be inherited; an in- heritance; value objects and qualities such as historic buildings and cultural traditions that have been passed down from previous generation'. Menurut UNESCO Brazil, heritage adalah warisan dari masa lalu yang kita hadapi hari ini dan akan diwariskan kembali pada generasi selanjutnya. Baik warisan budaya atau natural keduanya adalah sumberdaya yang tidak dapat tergantikan dalam hidup dan inspirasi, merupakan batu pijakan, titik rujukan, dan identitas kita $^{2}$. Kata 'heritage' berhubungan jelas dan relatif sederhana dengan konsep peninggalaninheritance, meskipun dalam bahasa Prancis kata hëritage secara eksklusif digunakan untuk memaknai warisan-legacy (Howard, 2003).

Penyebutan heritage memang masih terlalu luas dan dapat dipisahkan ke dalam dua aspek seperti yang dijelaskan pada laman UNESCO. Faktanya, heritage sendiri banyak disalahartikan sebagai warisan yang hanya berupa benda atau bangunan. Padahal, warisan budaya sendiri juga dibagi dalam dua kategori, yaitu warisan budaya benda (tangible) dan warisan budaya tak benda (intangible). Secara umum heritage disebut untuk menunjukkan objek, praktik, pengetahuan, dan lingkungan yang mempertahankan dunia budaya lintas generasi (Geismar, 2015).

Heritage yang tak nampak atau disebut 'intangible' antara lain bahasa, budaya, lagu populer, literatur atau busana. Jenis warisan ini penting untuk membantu memahami siapa kita sebagai objek fisik dan bangunan yang kita sebut sebagai 'heritage'(Howard, 2003). Di Indonesia, heritage diatur dalam Perpres Nomor 78 Tahun 2007 tentang Convention for the Safeguarding of the Intangible Cultural Heritage (Pengesahan Konvensi untuk Perlindungan Warisan Budaya Tak Benda). Pada Ketentuan Umum Pasal 1 Perpres Nomor 78 Tahun 2007, warisan budaya tak benda (intangible) diartikan sebagai:

"Berbagai praktik representasi, ekspresi, pengetahuan, keterampilan: serta instrumen-instrumen, objek, artefak,

\footnotetext{
${ }^{2}$ UNESCO Office in Brazil. "Heritage:Legacy from the Past to the Future", http://www.unesco.org/new/wn/ brasilia/culture/world-heritage/heritage-legacy-from-past-to-the-future/, diakses pada 4 Agustus 2019.
} 
dan lingkungan budaya yang terkait meliputi berbagai komunitas, kelompok, dan dalam beberapa hal tertentu, perseorangan yang diakui sebagai bagian warisan budaya mereka. Warisan budaya tak benda ini diwariskan dari generasi ke generasi, secara terus-menerus diciptakan kembali oleh berbagai komunitas dan kelompok sebagai tanggapan mereka terhadap lingkungannya, interaksi mereka dengan alam, serta sejarahnya, dan memberikan mereka makna jati diri dan keberlanjutan, untuk memajukan penghormatan keanekaragaman budaya dan kreatifitas manusia."

Berbicara mengenai heritage tidak semata-mata membahas tentang hal yang dapat dimanfaatkan atau bentuk heritage yang dapat kita lihat secara langsung. Geismar (2015) menyebut bahwa "heritage itu kompleks". Di dalam tulisannya berjudul "Anthropology and Heritage Regimes", ia berasumsi bahwa adanya rezim heritage yang secara fundamental bersifat material dan memunculkan hubungan kekuasaan membentuk politik pengakuan yang "licik".

Rezim heritage tidak hanya memandang heritage sebagai sesuatu yang tunggal; namun di dalamnya ada peran pemerintah dan politik atau negara yang ikut memainkan berbagai upaya (kebijakan, pratik, filosofi) dalam memproduksi heritage sehingga menjadikan heritage ini kuat. Kepentingan-kepentingan dalam menggarap rezim ini ikut menyeret korporasi swasta pula. Di samping itu, nasionalisme, kosmopolitanisme, dan internasionalisme dijadikan tata kelola yang dibangun dalam rezim ini dan ketiganya saling bersaing. Rezim heritage juga diperparah dengan kemunculan gerakan-gerakan yang justru menyebut diri mereka sebagai "anti heritage". Rezim heritage yang demikian ini mendapat kritik dari Michael Brown dengan argumennya, “...recent challenges to state heritage are misplaced tribalisms....can culture be copyright?" (Apiah dalam Geismar, 2015). Adanya rezim heritage juga banyak menggeser pemahaman tentang heritage dan dimanfaatkan oleh pemerintah dalam menjalankan politik pengakuan.
Geismar ikut mengkritisinya dengan menyebut bahwa rezim heritage ini mewujudkan asumsi tentang heritage sebagai seuatu properti.

\section{Discourse of Heritage}

Hall (2001) menyebutkan bahwa heritage adalah bagian dari social action. Gagasan wacana ini mengakui bahwa cara orang berbicara, diskusi dan memahami benda-benda, seperti heritage, memiliki konsekuensi materi yang penting (Smith, 2006). Praktik sosial dalam mengelola heritage ini didasarkan pada posisi aktor sosial (Fairclough, 2001), sehingga memahami konteks yang terjadi sekarang (Popper, dalam Sayer, 1992) dan apa yang mereka representasikan menjadi bagian dari proses konstruksi sosial dari praktik tersebut (Fairclough, 2001). Di dalam hal ini kesinambungan antara pengetahuan, praktik, dan social change adalah pendekatan penting untuk memahami suatu diskursus (Sayer , 1992; Fairclough, 1993 dalam Smith, 2006).

Pergeseran dalam kritik studi heritage dan kebijakan heritage telah beralih dari materials dan materiality heritage ke "keprihatinan pada heritage sebagai diskursus dan sistem nilai" (Harrison dan Smith dalam Geismar, 2015). Diskursus ini banyak digunakan oleh pemerhati heritage dalam upaya pelestarian yang kerap dikampanyekan. Terkadang, diskursus ini pun dibuat untuk menjaring dukungan dari berbagai pihak terhadap penyelamatan heritage.

Diskursus dapat didefiniskan sebagai kumpulan dari ide-ide, konsep, dan kategorisasi melalui pemaknaan yang diberikan pada suatu fenomena, dan argumen menjadi persoalan penting untuk menganalisis produksi wacana dan praktik sosial aktor terlibat (Hajer, 1996). Di samping itu, diskursus bukan semata-mata 'study of language', tetapi perlu digali analisis pada bagaimana bahasa digunakan untuk melakukan sesuatu atau 'how to do things' (Wetherell, 2001). Antropologi juga menggambarkan banyaknya diskursus heritage yang kompleks, yang diarahkan pada pengertian, "semua pekerjaan warisan pada dasarnya 
dimulai dari premis bahwa masa lalu diperebutkan, konfliktual, dan berlipat ganda" (Meskell dalam Geismar, 2015).

Menurut Smith (2006), ada dua diskursus penting dalam memahami heritage. Pertama, Authorized Heritage Discourse (AHD) yang memusatkan perhatiannya pada estetika objek, situs, tempat, dan lanskap yang generasi saat ini harus pedulikan, lindungi, dan dijunjung tinggi agar dapat diteruskan pada generasi di masa yang akan datang untuk pendidikan mereka, dan untuk menempa identitas kebersamaan berdasarkan masa lalu. Salah satu konsekuensi dari AHD adalah mendefinisikan siapa juru bicara yang melegitimasi masa lalu. Diskursus ini menekankan pada istilah 'the past' (masa lalu) karena selalu dianggap sebagai warisan untuk individu atau komunitas. Smith juga menekankan bahwa "masa lalu tidak dapat dengan mudah direduksi menjadi data arkeologi atau teks sejarah, karena itu adalah warisan (heritage)". Otoritas AHD banyak yang justru menampilkan retorika dengan dalil menyelamatkan heritage untuk generasi di masa depan dengan menggandeng profesional atau ahli di bidang ini dan menjadi diskursus yang dominan. Secara integral, AHD terikat dalam pembuatan daftar yang mewakili the canon of heritage (Harrison, 2010). Namun, yang absen dalam AHD adalah makna 'tindakan' atau ikatan kritik pada bagian pengguna heritage non-ahli, karena heritage adalah tentang menerima kebebasan dan pengetahuan dari sejarawan, arkeolog, dan ahli-ahli lainnya.

Kedua, subaltern dan dissenting heritage discourse. Ditilik dari namanya, diskursus kedua ini adalah lawan dari AHD. Graham, et al. dalam Smith (2006) menjelaskan bahwa heritage mungkin merepresentasikan ideologi diskursus dominan, tetapi juga memastikan bahwa itu dapat menjadi fokus alternatif untuk mereka yang tidak sepakat (dissent). Smith mengamati ada sejumlah perbedaan pendapat atau dissenting wacana dan kritik tentang alam, makna dan penggunaan heritage. Selain itu, dua hal yang perlu digarisbawahi yaitu, ekspresi partisipasi komunitas diskursus subaltern dalam manajemen heritage dan proses konservasi; dan bagian kedua dari uraian dissent adalah mengembangkan kritik dari 'heritage industry' Inggris dan pariwisata heritage yang lebih luas. Diskursus ini tidak dapat diidentifikasikan sebagai bagian dari diskursus 'subaltern' yang bekerja mengkritisi pembangunan, serta merespon institusi dan literatur heritage. Kelompok masyarakat yang mengembangkan diskursus dissenting ini bekerja di luar diskursus dominan. Mereka juga tidak mempekerjakan ahli khusus heritage, dan hal yang mereka lakukan tidak berada di bawah otoritas resmi.

Dua diskursus yang disampaikan oleh Smith menunjukkan bagaimana isu 'pelestarian' ini dilakukan, yaitu secara top-down atau bottom-up. Ada yang fokus pada upaya mempercantik objek, dan ada yang mengarah pada praktik antara masyarakat dan objeknya. Pada penelitian ini, dua konsep diskursus heritage ini menjadi bahan untuk melihat praktik-praktik yang merujuk pada tindakan revitalisasi yang dilakukan oleh komunitas Laboratorium Banten Girang (LBG). Konsep revitalisasi dalam KBBI diartikan sebagai proses, cara, perbuatan mengidupkan atau menggiatkan kembali. Hal-hal yang dilakukan oleh LBG adalah desain revitalisasi yang berbeda dari diskursus resmi dalam memperlakukan heritage.

\section{Metode}

Metode yang digunakan dalam penelitian ini adalah kualitatif. Teknik pengambilan data dilakukan secara partisipasi observasi dan wawancara mendalam. Penelitian dilakukan pada 15 Maret 2019 hingga 30 April 2019. Lokasi penelitian adalah wilayah Kota Serang, Banten, dan di Desa Sempu, Kecamatan Serang, Kota Serang, Banten. Desa Sempu dipilih sebagai lokasi penelitian karena merupakan lokasi keberadaan warisan budaya (benda) yaitu Situs Banten Girang dan basecamp dari komunitas Laboratorium Banten Girang. Situs Banten Girang adalah produk budaya pada masa Hindu-Budha yang sekaligus menjadi titik peralihan masa Hindu-Budha ke masa Islam (cikal bakal Kesultanan) di Banten. 
Wawancara mendalam dilakukan dengan para informan yang memiliki pengetahuan mengenai sejarah pra-Islam dan tertarik dengan pengenalan kembali tinggalannya di Banten. Informan utama adalah anggota komunitas Laboratorium Banten Girang. Kateori informan dibagi antara pendiri/penggagas dan anggota baru yang merupakan generasi milenial. Selain anggota komunitas LBG, informan lain dalam penelitian ini adalah warga sekitar Situs Banten Girang; kalangan milenial di luar anggota LBG; tokoh masyarakat; akademisi yang berkonsentrasi pada kebudayaan Banten; serta masyarakat umum. Wawancara terhadap masyarakat umum dilakukan guna menggali respon atau pendapat mereka mengenai upaya dimunculkannya kembali wacana (sejarah) pra-Islam di Banten.

Data mengenai aktivitas para anggota komunitas LBG yang sudah berlalu, didapatkan melalui wawancara dan dokumentasi yang dimiliki oleh LBG. Studi literatur juga dilakukan di dalam penelitian ini sebagai upaya mencari data sekunder guna memperdalam bahasan dalam tulisan ini.

\section{Hasil dan Pembahasan}

\section{Menapaki Jejak Sejarah Pra-Islam di Banten}

Banten pernah menjadi bagian dari Provinsi Jawa Barat dan resmi dimekarkan pada 22 Oktober 2000. Secara umum Banten dikenal dengan kesultanannya tidak lepas dari sejarah penaklukan kerajaan bercorak Hindu-Budha terakhir, yaitu Banten Girang dengan tokohnya Prabu Pucuk Umun. Berakhirnya masa pra-Islam ini ditandai dengan mitos "pertarungan ayam jago" dengan perjanjian apabila Hasanuddin menang, Pucuk Umun harus bersedia menganut agama Islam. Singkat cerita, Pucuk Umun mengambil besi dan baja yang diubahnya menjadi ayam "jago galak", sedangkan Hasanuddin justru meminta santrinya untuk mengubah diri menjadi ayam "jago putih".

Di dalam kisah ini, Hasanuddin berhasil mengalahkan Prabu Pucuk Umun di Wahanten Girang (Banten Girang) pada tahun 1525.
Namun, Pucuk Umun mengkhianati janjinya dengan melarikan diri ke arah selatan, ke wilayah yang diyakini kini didiami oleh orang Baduy. Namun, terdapat banyak versi dari kisah ini karena asal-usul latar belakang sejarah masyarakat Baduy masih belum jelas (Sucipto dan Limbeng, 2007). Sucipto dan Limbeng dalam tulisannya "Studi tentang Religi Masyarakat Baduy di Desa Kanekes Provinsi Banten" mengumpulkan beberapa pendapat ahli mengenai asal-usul Baduy, antara lain Pleyte (1909) menganggap bahwa orang Baduy berasal dari daerah Bogor, Padjajaran; Jacob dan Meijer (1891) mengemukakan bahwa orang Baduy melarikan diri dari pengaruh Islam yang dipimpin oleh Maulana Hasanuddin yang diperkirakan dari Banten Utara. Krusemen dan Penning berpendapat bahwa orang Baduy adalah penduduk asli Banten yang menyatakan dirinya sebagai keturunan Padjajaran yang terdesak oleh Maulana Hasanuddin pada abad ke-16 (1579-1580); dan Garna beranggapan bahwa sebutan Baduy diberikan oleh penduduk Banten Selatan yang sudah menganut agama Islam. Penulis-penulis Belanda menyebut kelompok ini dengan sebutan badoe'i, badoej, badoewi, orang Kanekes dan Rawayan (Van Hoevell, 1845; Jacob dan Meijer, 1909; Pleyte, 1909; Van Tricht, 1929; dan Geise, 1952 dalam Sucipto dan Limbeng 2007).

Setelah kepergian Pucuk Umun, terjadilah peralihan kekuasaan dan pusat pemerintahan Banten dari pedalaman Wahanten Girang ke Surosowan pada tanggal 8 Oktober 1526, bertepatan dengan tanggal 1 Muharram 933 Hijriah atau dikenal dengan 1 Syuro. Momen itu dipercaya merupakan hari yang baik (Halwany dan Chudari, 1993). Kesultanan Banten berhasil mengalami kemajuan dalam berbagai bidang. Namun, sayangnya pada 1682, kesultanan mulai mengalami keruntuhan. Hal ini diawali dengan riwayat pengkhianatan Sultan Haji.

Hasil penggalian arkeologis yang dilakukan di situs Banten Girang dan wilayah lain, ditemukan data baru yang sejalan dengan pernyataan Lombard dalam kata sambutannya di buku Banten Sebelum Zaman Islam: Kajian 
Arkeologi di Banten Girang 932? - 1526. Lombard menjelaskan bahwa kesultanan-kesultanan seperti Malaka, yang mulai abad ke-16 menjamur di Kepulauan Nusantara, sesungguhnya hanyalah kelanjutan dari pusat-pusat niaga yang lebih tua, yang kendatipun lebih kecil, tetapi sama terbukanya terhadap laut bebas (Guillot et al., 1997).

Kesultanan Banten yang kini tidak lagi ada, sangat dirindukan kejayaannya oleh sebagian besar masyarakat Banten. Wacana untuk menggali sejarah dan kearifannya mulai dimunculkan pada ranah publik secara luas. Pemerintah pun ikut melakukan tindakan nyata dengan melakukan revitalisasi pada kawasan yang menyimpan jejak kesultanan, yaitu Kawasan Banten Lama atau yang kini disebut dengan Kawasan Kesultanan Banten. Wilayah ini kini menjadi primadona Banten tidak hanya untuk wisata sejarah, tetapi juga wisata religi. Lalu bagaimana dengan sejarah pra-Islam dan tinggalannya?

Pemahaman sejarah pra-Islam di kalangan masyarakat Banten masih sangat terbatas. Selain literatur, latar belakang kultural yang dipengaruhi oleh masa lalu yang dikembangkan dalam cerita sejarah juga membentuk pola pikir masyarakat dan cara menghargai sejarah. Hal inilah yang kemudian memicu terbaginya sejarah menjadi sejarah dominan (berkaitan dengan kesultanan atau pasca Islam masuk di Banten) dan sejarah tidak dominan (masa pra-Islam) di masyarakat. Perlakuan masyarakat terhadap warisan budaya juga dipengaruhi oleh kondisi yang berbeda dengan kepercayaan dan kultur yang dipeluk masyarakat sekitar cagar budaya saat ini yang berpengaruh pada penghargaan terhadap cagar budaya, sehingga dapat mengalami pergeseran (Susanto dalam Prabowo dan Ma'ruf, 2016).

Merespon fenomena ini, sekelompok orang membentuk komunitas "Laboratorium Banten Girang" pada 2016. Para pendiri dan anggotanya berasal dari berbagai latar belakang, yaitu seniman, sejarawan, arkeolog, hingga mahasiswa. Laboratorium Banten Girang
(LBG) bergerak atas nama kebudayaan dan mengambil sikap sebagai anti-tesis dari euforia kesultanan yang merupakan sejarah dominan di Banten. Uniknya, dalam upaya pengenalan kembali sejarah pra-Islam Banten, mereka juga menggunakan "kedok" kesenian yang dimanfaatkan untuk menarik anak muda Banten, khususnya Kota Serang untuk kemudian dijadikan sebagai media memaparkan pendidikan kesejarahan. Mereka menggunakan lokasi situs sejarah pra-Islam, Situs Banten Girang, yang merupakan bekas wilayah transisi kerajaan masa Hindu-Budha ke masa Islam (kesultanan) yang terletak di Desa Sempu, Serang sebagai tempat berkegiatan.

Sebagian besar kegiatan yang diadakan oleh LBG di Situs Banten Girang adalah bentuk pemanfaatan warisan budaya dan upaya memperkuat nilai-nilai dari warisan budaya, antara lain nilai sejarah, nilai ilmu pengetahuan, nilai kebudayaan, nilai spiritual, dan nilai ekonomis. Nilai-nilai yang terkandung dalam budaya masa lampau ini digunakan sebagai pembelajaran, sehingga masa lampau beserta nilai-nilainya lekat dengan kehidupan masyarakat sehari-hari (Taniardi, 2013). Hadiyanta (2017) menjelaskan bahwa potensi warisan budaya yang berwujud (tangible) ini dapat ditetapkan sebagai cagar budaya berdasarkan nilai penting yang dikandungnya. Hadiyanta juga menambahkan bahwa keunikan cagar budaya tersebut eksistensinya mempunyai koherensi dengan konteks kultural era yang melatarbelakanginya.

Kegiatan yang dilakukan oleh LBG sedikit menggeser konsepsi masyarakat terhadap mitos dan kesakralan yang melekat pada warisan budaya. Namun, LBG beranggapan bahwa warisan budaya, dalam konteks ini Situs Banten Girang, adalah situs utama. Situs ini digunakan sebagai ruang publik; dan dapat dimanfaatkan oleh publik, tanpa terkecuali. Ruang publik sendiri merupakan ruang atau lahan umum, tempat masyarakat dapat melakukan berbagai kegiatan publik fungsional maupun kegiatan sampingan lainnya, yang dapat mengikat suatu komunitas yang di dalamnya juga terjalin interaksi sosial (Carr dalam 
Dewi, 2015). Penggunaan ruang publik dalam berbagai aktivitas LBG ini berkaitan dengan konsep ruang yang oleh Tuan (1977) dimaknai sebagai kebebasan yang lebih abstrak dari "tempat". Di ruang publik ini, LBG dapat bebas mengekspresikan diri dan menampilkan karya mereka di hadapan publik, sekaligus berinteraksi dengan komunitas lain dan mencari pengakuan oleh publik atas eksistensi mereka. Sejauh ini LBG lebih dikenal sebagai komunitas teater, bukan komunitas yang juga melakukan pengenalan sejarah. Penggunaan ruang publik dapat sekaligus menjadi promosi kegiatan berbasis sejarah yang LBG usung.

Di samping itu, penggunaan situs sebagai tempat berkegiatan bukan tanpa memperhatikan keberlanjutan. Pemanfaatan ini diharapkan akan menimbulkan efek domino pada situs yang digunakan untuk berkegiatan. Dikenalnya kembali situs oleh publik secara luas, maka akan dikenali pula sejarahnya yang berkaitan dengan masa-masa sebelumnya. Dengan demikian, terjadilah proses edukasi kesejarahan dan pelestarian terhadap warisan budaya. Membuka kembali sejarah yang telah terkubur dan mulai terkaburkan tentu bukan hal mudah. Namun, hal inilah yang menjadi bidikan LBG dan mungkin pihak-pihak lain demi kepentingan pendidikan kesejarahan, sehingga tidak berat sebelah dalam membahas sejarah Banten.

\section{Kesenian dan Upaya Memaparkan Pendi- dikan Kesejarahan}

Kemampuan anggota Laboratorium Banten Girang sudah tidak diragukan lagi dalam hal teater. Berbagai judul pertunjukan telah dipentaskannya. Pementasan pun telah dilakukan di berbagai wilayah di Banten dan sekitarnya, baik dari inisiatif LBG maupun undangan dari suatu acara. Menariknya, kegiatan pertunjukan keliling (inisiatif) yang dilakukan secara mandiri dapat berlangsung salah satunya berkat bantuan "Susutante" atau "Sumbangan Sukarela Tanpa Tekanan". Susutante dilakukan dengan cara "ngamen gembira", di mana anggota LBG melakukan berbagai kegiatan, seperti baca pui- si, akustik, hingga pentas di ruang publik dengan bayaran seikhlasnya dari penonton. Dana hasil pengumpulan Susutante digunakan sesuai keperluan, seperti pembuatan artistik panggung, akomodasi perjalanan LBG, kegiatan sosial, dan lain-lain.

Selain kesenian teater, pada dasarnya Laboratorium Banten Girang memiliki dua rancangan kegiatan utama, yaitu kelas pertunjukan dan kelas menulis. Secara umum, program LBG dibagi menjadi empat bidang, yaitu seni/budaya (kelas pertunjukan, kelas menulis, teater, tari, marawis, dan film), sejarah (kelas riset, reading club, nyusur tutur), social movement (situs baca/perpustakaan kampung, penanggulangan bencana di kampung adat/area situs), dan ekonomi kreatif (kuliner, kukuyan/gondala, history trip, merchandise/handicraft, dan homestay). Berdasarkan rancangan program tersebut, beberapa kegiatan yang telah berjalan, antara lain program pertunjukan (judul: Cipoa I, II, III; Kalacikahuripan; Buto Kalarakus; Babi-babi Sangiang), program literasi (partisipasi dalam keliling Kuda Pustaka, Situs Baca (Perpustakaan Kampung), Reading Club Cagar Budaya), program pemeliharaan situs (bersih-bersih situs, menanam pohon untuk memperkuat bantaran Sungai Cibanten, pendataan artefak), program kelas sejarah dan kelas pertunjukan, program bakti sosial (berpartisipasi dalam kegiatan penanggulangan bencana di Banten), dan program nyusur tutur ${ }^{3}$ (Situs Salakanagara, Situs Batu Lingga Baros, Bandungan Pamarayan, dan Situs Patapan). Beberapa program lainnya belum terlaksana dan masih dalam proses pengembangan. Secara keseluruhan program-program LBG yang sudah terlaksana belum berkelanjutan.

Kelas pertunjukan menjadi yang paling diminati oleh mereka yang ingin bergabung dengan LBG. Hal ini dimanfaatkan oleh fasilitator LBG untuk memaparkan pendidikan kesejarahan, dimulai dari sejarah Banten Girang yang dekat dengan mereka. Sebagian besar generasi muda yang bergabung tidak mengetahui sejarah pra-Islam di Banten beserta tinggalannya. Inilah

\footnotetext{
${ }^{3}$ Istilah 'nyusur tutur' yang digunakan oleh LBG untuk menyebut kegiatan berjalan di pinggir sungai peradaban atau mendatangi warisan budaya (benda) untuk menggali nilai-nilainya dan memaknai kehidupan di masa itu.
} 
yang kemudian mereka sebut dengan metode "jebakan". Metode jebakan ini baru disadari oleh anggota baru setelah bergabung dalam komunitas LBG. Bersifat informal, edukasi kesejarahan yang dilakukan menjadi bekal bagi generasi muda yang ikut untuk memahami Banten.

\section{Menghadang "Amnesia Budaya", Mence- tak Kuncen Milenial}

Perkembangan sejarah di Banten dinilai oleh LBG banyak yang perlu dibongkar kembali. Masih sedikit kajian sejarah di luar sejarah dominan yang dapat dinikmati oleh publik, termasuk untuk kepentingan ilmu pengetahuan. Adanya perbedaan perlakuan terhadap sejarah beserta tinggalannya tidak menutup kemungkinan dapat menjadi gerbang "amnesia budaya" yang merujuk pada sejarah tidak dominan.

Hoed (2016) menjelaskan pentingnya memaknai tonggak budaya melalui anchorage. Anchorage adalah upaya untuk memahami sejarah dan kearifan lokal agar suatu bangsa dapat memahami sejarah dan kearifan lokal, sehingga dapat memahami pula kesalahan maupun keberhasilan pendahulunya di masa yang lalu. Hoed menegaskan bahwa upaya ini perlu dilakukan untuk "mengingatkan" eksistensi dan makna berbagai tonggak budaya agar tidak terkikis oleh gejala amnesia budaya.

Berkaitan dengan upaya mempertahankan eksistensi warisan budaya, Laboratorium Banten Girang berusaha mengenalkan (kembali) arti penting suatu peninggalan sejarah dan melakukan upaya penyelamatan, memulai aksinya dari situs Banten Girang. Selain penggunaan situs sejarah sebagai ruang publik, Laboratorium Banten Girang memanifesto Banten Girang sebagai lokasi terjadinya peristiwa-peristiwa sejarah, salah satu dari peninggalan di Banten yang terhitung banyak.

LBG menggagas Lima-K, yaitu Kampung (komunitas), Kampus, Kantor (pemerintah), Korporat (pengusaha), dan Koran (media

\footnotetext{
${ }^{4}$ Merujuk pada istilah yang digunakan oleh Hoed (2016) dalam tulisannya berjudul "Amnesia Budaya sebagai
} Gejala Krisis dalam Kebudayaan Indonesia”. massa), untuk mengupayakan kemajuan kebudayaan, yang mengacu pada penyelamatan situs sejarah. Salah satu komponen utama dalam hal ini adalah 'kampung' atau masyarakat sekitar situs. Masyarakat memegang peranan penting untuk mendukung kegiatan penyelamatan. Hidup berdampingan dengan situs bersejarah tidak sekadar menikmati manfaat dari keberadaan situs, meskipun kepentingan mengambil manfaat dari warisan budaya karena warisan budaya memang memiliki nilai penting bagi berbagai pihak (Tanudirjo, 2003). Timbulnya kesadaran masyarakat bahwa situs tersebut penting untuk dilestarikan adalah harapan LBG. Situs Banten Girang adalah satu dari sekian banyak situs atau peninggalan pra-Islam di Banten yang memerlukan perhatian, baik dari masyarakat sekitar, komunitas, maupun pemangku kebijakan. Namun, di dalam perjalanannya, kolaborasi Lima-K belum berjalan efektif dan masih belum menjangkau semua sasaran.

Sebagai komunitas tunggal yang bergerak dalam pelestarian cagar budaya, upaya yang dilakukan oleh LBG dapat dikatakan bagian dari 'history from below' yang menggunakan heritage untuk bermain di tataran masyarakat (Harrison, 2010). Samuel dalam Harrison (2010) mendukung pentingnya non-institusional dan komunitas yang berbasis sejarah. Ia menyebut bahwa 'people history' atau 'history from below' berpotensi tidak hanya bermanfaat bagi komunitas lokal tetapi juga dapat mempengaruhi akademik disiplin sejarah. Namun, dalam praktiknya LBG juga membutuhkan komponen lain, seperti kantor (pemerintah) untuk mendukung kegiatan mereka. Hal ini sedang diupayakan oleh Laboratorium Banten Girang (LBG).

Pada dasarnya pengelola warisan budaya juga ikut memegang peran sebagai mediator dalam masalah-masalah yang dihadapi oleh masyarakat, mampu memberikan pendapat dalam diskusi dan debat publik, dan memberikan narasi-narasi tentang warisan budaya yang penting dan relevan dengan masalah yang 
ada di masa ini (Tanudirjo, 2003). Selain itu, pengelolaan warisan budaya juga diharapkan dapat kritis melihat bagaimana kepentingan masa kini mempengaruhi interpretasi masa lampau. Pengelola warisan budaya harus peka terhadap keragaman minat dan kepentingan akan masa lampau di masa kini dan dampaknya terhadap kualitas sumber daya arkeologi yang tersedia (Hodder, 1999). Oleh karena itu, pengelolaan warisan budaya harus didukung dengan lembaga yang luas kewenangan atau jaringan kerjanya (Tanudirjo, 2003).

Sejauh ini kegiatan Laboratorium Banten Girang yang berbasis kesejarahan masih dilakukan secara mandiri, sehingga sinergitas antar komponen Lima-K belum terjalin harmoni. Keterlibatan pemerintah yang juga bagian dari agen cagar budaya belum maksimal. Padahal mereka perlu memperjuangkan cultural heritage, dan nilai yang diberikan kepada cagar budaya tersebut (Byrne, 2008).

LBG melengkapi misi kebudayaan yang diusung dalam mengenalkan kembali sejarah pra-Islam di Banten, dengan mencetak kuncen milenial bidang sejarah. Istilah kuncen milenial atau kuncen modern yang ditujukan kepada anggota LBG ini disampaikan oleh Mas Radjimo, sejarawan dan fasilitator penelitian, sekaligus pendiri LBG. Kuncen milenial yang dimaksudkan bukan merujuk pada penjelasan dan praktik dari sisi mistis atau spiritual dari tempat yang dijaga, melainkan menjadi kuncen dari sisi akademis. Kuncen harus mampu menjelaskan tentang sejarah Banten yang berkaitan dengan situs dan membuka diskusi dengan akademisi lain maupun pengunjung yang datang.

Peran kuncen milenial ini didukung oleh Museum Banten Girang. Museum ini menyimpan artefak dari beberapa tahap penggalian yang dilakukan antara Indonesia dengan Paris. Sebelumnya museum ini disebut Balai Penyelamatan Artefak yang menampung berbagai temuan, baik dari ekskavasi maupun temuan masyarakat sekitar. Selain disimpan di museum ini, beberapa temuan di Banten Girang yang ditempatkan di Museum Nasional.
Pada April 2019, dilakukan pendataan kembali koleksi pada Museum Banten Girang. Kegiatan ini merupakan kerja sama dengan BPCB Banten. Pendataan ini kemudian dicocokkan dengan data artefak yang ada di BPCB dan buku tulisan Claude Guillot yang berisi data-data artefak dari hasil ekskavasinya. Lebih dari itu, angin segar pun menghampiri LBG dengan semakin terbukanya koneksi dengan lembaga pemerintahan yang menerima wacana mengangkat kembali sejarah pra-Islam yang mereka usung. Kegiatan diawali dengan diskusi "membaca ulang" sejarah dengan arkeolog hingga dukungan BPCB melalui sosialisasi bertema "Pemberdayaan Masyarakat Peduli Cagar Budaya dalam Pelestarian di Situs Banten Girang". Kegiatan menyuarakan pentingnya sejarah dan pelestarian warisan budaya semakin gencar dilakukan oleh LBG sebagai gerbang membuka katup kebudayaan yang selama ini dianggap masih tertutup di Banten.

\section{Respon Masyarakat terhadap Pengenalan Kembali Sejarah Pra-Islam}

Mengangkat isu lama merupakan hal baru bagi masyarakat Banten. Hal ini merupakan sebuah tantangan bagi LBG maupun pihak lain dalam menyuarakan kepedulian terhadap kebudayaan secara holistik dimulai dari masa pra-Islam. Sejauh ini, berbagai pihak belum seragam dalam menanggapi proses pengenalan kembali sejarah pra-Islam dan tinggalannya, baik dari masyarakat sekitar situs maupun Kota Serang secara luas. Hal ini dapat dilihat dari keanggotaan komunitas LBG. Sebagian besar anggota LBG justru berasal dari luar situs tempatan (Situs Banten Girang) yang digunakan untuk berkegiatan. Partisipasi dari warga sekitar situs justru masih sangat minim dan belum konsisten. Sebagian masyarakat masih keberatan dan terpaku pada perdebatan pantas-tidak, benar-salah, bahkan tauhid-musyrik dalam memandang kebudayaan. Hal ini menjadi hambatan LBG dalam upaya membuka pemahaman masyarakat terhadap pentingnya sejarah yang ikut berperan dalam perkembangan kebudayaan Banten.

Berdasarkan hasil wawancara, sebagian war- 
ga Desa Sempu belum memahami tujuan dari kegiatan yang dilakukan oleh LBG, terutama dalam bidang kesejarahan. Hal ini karena kesenian teater lebih terlihat menonjol dengan latihan yang intensif, yang membuat warga justru menyayangkan kegiatan yang menggunakan suara lantang tersebut dilakukan pada tempat yang dianggap sakral. Di samping itu, masih terdapat beberapa orang tua yang tidak mengizinkan putra-putrinya mengikuti kegiatan LBG karena dianggap tidak sesuai dengan prinsip mereka. Sebaliknya, sebagian generasi muda sekitar Situs Banten Girang mulai memiliki keinginan untuk mengikuti kegiatan LBG dan terpupuk rasa keingintahuan terhadap sejarah yang ada di wilayah tempat tinggal mereka.

Sejauh ini partisipasi masyarakat sekitar situs masih berada dalam tataran partisipasi pada kegiatan hiburan dan hal-hal insidental (contoh: membersihkan Goa Banten Girang karena banjir). Keikutsertaan dalam kegiatan pokok, terutama yang berkaitan dengan kesejarahan dan penyelamatan situs belum terlalu nampak. Hal ini mencerminkan hal yang oleh Spiridon dan Sandu (2015) disebut sebagai involuntary participation "by use" pada tipologi partisipasi masyarakat dalam proses konservasi.

"This level is most often found in communities where the members only "use" the heritage and they are just receivers of the general information regarding cultural heritage assets in an informal way and participation is simply a pretence." (Spiridon dan Sandu, 2015)

LBG mengharap kehadiran masyarakat dalam berbagai momentum yang dibuat; tidak hanya menikmati sekadar pertunjukan, tetapi juga mengetahui keberadaan situs sejarah yang digunakan. Bagnall dalam Smith (2006) menekankan bahwa "the idea that visiting heritage sites is a physical experience of performance and reminiscing". Generasi atau kelompok usia berbeda akan memiliki pengalaman berbeda pada sejarah (Colson, 1948; Rosaldo, 1980 dalam Byrne, 2008) dan signifikansi atau makna dari warisan budaya adalah secara bersamaan diwarisi dan diciptakan kembali oleh yang hidup (Byrne, 2008).

Berkaitan dengan kegiatan yang dilakukan LBG, secara umum termasuk dalam tipologi volunteer/spontanerous participation milik Spridon dan Sandu yang merujuk pada karakteristik sebagai berikut:

"The community members participate
by taking initiatives - spontaneous or
organised-independently of external
institution in order to change system
and retain control over how resourc-
es are used. As group take control of
local decisions and determine how
available resources are used, so they
have a stake in maintaining struc-
tures or practices. Self-mobilisation
and volunteering is in fact an active
way to reflect different approaches
and traditions based on free choice,
desire and motivation. At this level
the people do not request reward as
they are conscious of their contri-
bution to the general interests of the
community or society." (Spiridon dan
Sandu, 2015)
Sandu, 2015)

Komunitas Laboratorium Banten Girang yang notabene adalah pendatang di Desa Sempu, telah berusaha mengenalkan kembali sejarah pra-Islam kepada masyarakat yang berada di lingkungan situs dan masyarakat secara luas. Lebih dari itu, LBG juga ambil bagian dalam upaya pelestarian warisan budaya dan menjadi penghubung dalam upaya penyelamatan Situs Banten Girang kepada pemerintah - BPCB. Di dalam hal ini, secara tidak langsung LBG juga mengambil kontrol terhadap warisan budaya, mulai dari pemanfaatan situs hingga menjalin kerja sama dengan pemerintah maupun stakeholder lain. Di satu sisi, dalam hubungannya dengan publik dan arkeologi, kegiatan LBG merujuk pada UU Cagar Budaya Nomor 11 Tahun 2010 pasal 85, yaitu cagar budaya dapat dimanfaatkan untuk bidang agama, sosial, pendidikan, ilmu pengetahuan, teknologi, kebudayaan, dan pariwisata. Di sisi 
akademis, pemanfaatan objek arkeologi dapat dikategorikan sebagai inspirasi, hiburan, edukasi, ekonomis, dan ideologis. Hal ini beriringan dengan kegiatan yang dilakukan oleh LBG dalam pemanfaatan situs sejarah sebagai ruang publik dengan berbagai tujuan.

\section{Simpulan}

Laboratorium Banten Girang (LBG) adalah satu komunitas yang mengambil wacana berbeda demi kepentingan kebudayaan. Kegiatan yang mereka lakukan memiliki tempat tersendiri; sebab sejarah tidak dominan yang merujuk pada sejarah pra-Islam di Banten belum banyak disentuh oleh banyak pihak di Banten. LBG tidak terang-terangan menyebut diri sebagai komunitas sejarah, tetapi mereka mampu menarik minat anak muda Banten untuk turut mempelajari sejarah melalui kesenian, yaitu teater.

Mengacu pada penjelasan Smith mengenai the discourse of heritage, kegiatan yang dilakukan oleh LBG termasuk dalam dissenting heritage discourse. Aktivitas kesejarahan yang dilakukan oleh LBG tidak berusaha mengubah atau mempercantik warisan budaya yang ada. Namun, mereka mencoba mengenalkan kembali sejarah pra-Islam beserta tinggalannya kepada generasi muda di luar perintah resmi pemangku kebijakan. Praktik yang dilakukan LBG sejalan dengan ide-ide terhadap pelestarian warisan budaya dan pemanfaatan ruang publik. Inisiatif LBG ini sebagai upaya memahami kebudayaan Banten yang tidak hanya berpusar pada sejarah dominan (kesultanan) yang telah dikenal oleh masyarakat. Masih banyak sejarah yang belum diungkap dan memerlukan kajian lebih dalam. Oleh karena itu, dimulai dengan hal yang sederhana, LBG berharap masyarakat dapat bersikap adil dan peka terhadap kebudayaan. Di dalam ranah pelestarian warisan budaya, LBG tidak dapat berdiri sendiri dalam mewujudkan wacana-wacana yang telah dibangun. Mereka memerlukan sinergitas dengan para pengelola warisan budaya, termasuk pemerintah, dan masyarakat luas untuk menghasilkan Banten yang tidak lagi disebut memiliki "katup kebudayaan yang tertutup".

\section{Daftar Pustaka}

Ayatrohaedi. (1995). Banten Sebelum Islam. Dalam Banten Kota Pelabuhan Jalan Sutra. Jakarta: CV Dwi Jaya Karya.

Byrne, D. (2008). Heritage Conservation as Social Action. Dalam R. Harrison, J. Jameson, dan J. Schofield (Eds.), The Cultural Heritage Reader. London: Routledge.

Cortesão, A. (2018). The Suma Oriental of Tomé Pires. Dalam The Suma Oriental of Tomé Pires. Abingdon: Taylor \& Francis.

Dewi, D. I. K. (2015). Pemanfaatan Ruang Terbuka Publik Berdasarkan Gaya Hidup di Kota Semarang. Conference on Urban Studies and Development.

Fairclough, N. (2001). The Discourse of New Labour: Critical Discourse Analysis. Dalam M. Wetherell, S. Taylor, dan S. J. Yates (Eds.), Discourse as Data: A Guide for Analysis. London: Sage.

Gasani, M. El. (2019). Pemberdayaan Masyarakat melalui Kegiatan Seni di Komunitas Celah-Celah Langit (KCCL). Umbara, $4(1), 1-14$.

Geismar, H. (2015). Anthropology and Heritage Regimes. Annual Review of Anthropology, 44, 71-85.

Guillot, C., Nurhakim, L., Wibisono, S., Adhyatman, S., dan École française d'Extrême-Orient. (1997). Banten Sebelum Zaman Islam: Kajian Arkeologi di Banten Girang (932?1526). Jakarta: Departemen Pendidikan dan Kebudayaan.

Hadiyanta, I. E. (2017). Arti Penting Membangun Pembelajaran Pelestarian Cagar Budaya. Dalam Dinamika Pelestarian Cagar Budaya (pp. 53-56). Yogyakarta: Ombak.

Hajer, M. (1996). Discourse Coalitions and the Institutionalisation of Practice: The Case of Acid Rain in Britain. Dalam F. Fischer dan J. Forester (Eds.), The Argumentative Turn in Policy Analysis and Planning. Durham: Taylor \& Francis.

Hall, S. (2001). Foucault: Power, Knowledge and Discourse. Dalam M. Wetherell, S. Taylor, \& S. J. Yates (Eds.), Discourse Theory and Practice: A Reader. London: Sage.

Halwany, M., dalam Chudari, A. M. (1993). Catatan Masa Lalu Banten. Serang: Sausara.

Hariana, K. (2017). Banten Canang Sari sebagai Identitas Budaya Bali dalam Pewarisan Pendidikan Estetika dan Ecoart di Sulawesi Tengah. Seminar Nasional Seni Dan Desain 
2017, 58-68. Universitas Negeri Surabaya.

Harrison, R. (2010). What is Heritage. Dalam R. Harrison (Ed.), Understanding the Politics of Heritage. London: Manchester University Press.

Hodder, I. (1999). The Archaeological Process, an Introduction. Oxford: Blackwell.

Hoed, B. H. (2016). Amnesia Budaya sebagai Gejala Krisis dalam Kebudayaan Indonesia. Jakarta: Yayasan Pustaka Obor Indonesia.

Howard, P. (2003). Heritage: Management, Interpretation, Identity. London: Continuum.

Humaeni, A. (2016). Akulturasi Islam dan Budaya Lokal dalam Magi Banten. Serang: Bantenologi.

Kelley, D. R. (1998). Faces of History: Historical Inquiry from Herodotus to Herder. New Conn: Yale University Press.

Marbun, J. (2016). Model Partisipasi Publik dalam Pelestarian Situs Biting, Lumajang, Jawa Timur. Universitas Gadjah Mada.

Prabowo, D. A., dan Ma'ruf, M. F. (2016). Partisipasi Masyarakat dalam Pengembangan Cagar Budaya sebagai Ruang Publik: Studi Kasus Gedung Balai Pemuda Kota Surabaya. Publika, 4(11).

Sayer, A. (1984). Method in Social Science: A Realist Approach. London: Hutchinson.

Smith, L. (2006). Uses of Heritage. London: Routledge.

Spiridon, P., dan Sandu, I. (2015). Conservation of Cultural Heritage: from Participation to Collaboration. ENCATC Journal of Cultural Management and Policy, 5(1), 43-52.

Sucipto, T., dan Limbeng, J. (2007). Studi tentang Religi Masyarakat Baduy Desa Kanekes Provinsi Banten. Jakarta: Departemen Kebudayaan dan Pariwisata Direktorat Jenderal Nilai Budaya Seni dan Film-Direktorat Kepercayaan terhadap Tuhan Yang Maha Esa.

Taniardi, P. N. (2013). Video (berbasis) Komunitas: Sebuah Alternatif Penelitian Arkeologi Partisipatif. Dalam A. Sumijati dan P. Tjahjono (Eds.), Arkeologi dan Publik. Yogyakarta: Kepel Press.

Tanudirjo, D. A. (2003). Warisan Budaya untuk Semua: Arah Kebijakan Pengelolaan Warisan Budaya di Indonesia di Masa Mendatang. Kongres Kebudayaan V, Bukittinggi.

Tihami, H. M. A. (2018). Potret Budaya Banten Dulu, Kini, dan Nanti. Dikutip dari http:// bantenologi.uinbanten.ac.id/?p=218.

Tuan, Y.-F. (1977). Space and Place: The Perspective of Experience. Minneapolis: Univeristy of Minnesota Press.

UNESCO Office in Brazil. (n.d.). Heritage: Legacy from the Past to the Future. Retrieved from http://www.unesco.org/new/en/brasil$\mathrm{ia} /$ culture/world-heritage/heritage-legacyfrom-past-to-the-future/, dikutip 4 Agustus 2019

Wetherell, M. (2001). Introduction. Dalam M. Wetherell, S. Taylor, \& S. Yates (Eds.), Discourse Theory and Practice. London: Sage.

Wiana, I. K. (2007). Tri Hita Karana Menurut Konsep Hindu. Surabaya: Paramita. 